\title{
SISTEM PAKAR PENYAKIT DI DAERAH TROPIS PADA ANAK BERBASIS WEB
}

\author{
Rian Haris Muda Nasution ${ }^{1)}$, Oky Dwi Nurhayati' ${ }^{2}$, Rinta Kridalukmana ${ }^{3)}$ \\ Jurusan Teknik Sistem Komputer, Fakultas Teknik, Universitas Diponegoro \\ Jl. Prof. Sudharto, Tembalang, Semarang \\ email : rian.nasution28@gmail.com
}

\begin{abstract}
ABSTRAK
Perkembangan ilmu kedokteran mengalami kemajuan pesat yang ditandai dengan ditemukannya penyakitpenyakit tropis baru yang belum teridentifikasi sebelumnya. Para dokter ahli terus mencoba menemukan solusi untuk mengatasi penemuan baru dan selalu mencoba memberikan pelayanan terbaik terhadap para pasien. Kesehatan merupakan hal yang berharga bagi manusia, karena siapa saja dapat mengalami gangguan kesehatan. Anak sangat rentan terhadap kuman penyakit dan kurangnya kepekaan terhadap gejala suatu penyakit merupakan ketakutan tersendiri bagi orang tua, oleh sebab itu penulis membuat aplikasi sistem Pakar demam berdarah untuk membantu para orang tua dalam mengidentifikasi penyakit demam berdarah berdasarkan gejala.

Pada penelitian ini penulis membuat suatu penerapan metode untuk penyusunan laporan Tugas Akhir ini adalah metode penelitian kuantitatif yang meliputi studi pustaka, observasi dan wawancara. Teknik pengembangan sistem perangkat lunak dilakukan dengan metode waterfall. Metode waterfall meliputi beberapa proses diantaranya definisi kebutuhan, analisis, design, coding, pengujian dan perawatan.

Berdasarkan hasil pengujian alpha dan betha, aplikasi yang dibangun sudah berjalan cukup maksimal, tetapi tidak menutup kemungkinan dapat terjadi kesalahan dan kekurangan pada saat aplikasi digunakan. Hasil pengujian mampu membedakan jenis penyakit demam dengue, demam berdarah dengue da syok syndrome dengue. Hasil penelitian yang sudah dilakukan, hasil pengujian alpha memberikan hasil bahwa aplikasi berjalan cukup maksimal tetapi tidak menutup kemungkinan dapat terjadi kesalahan pada suatu aplikasi yang digunakan dan hasil pengujian betha adalah $67.00 \%$.
\end{abstract}

Kata Kunci : Waterfall, Demam Berdarah, Pengguna, Pakar, Gejala

\section{PENDAHULUAN}

\subsection{Latar Belakang}

Perkembangan ilmu kedokteran mengalami kemajuan pesat yang ditandai dengan ditemukannya penyakit-penyakit tropis baru yang belum teridentifikasi sebelumnya. Para dokter ahli terus mencoba menemukan solusi untuk mengatasi penemuan baru dan selalu mencoba memberikan pelayanan terbaik terhadap para pasien.

Kesehatan merupakan hal yang berharga bagi manusia, karena siapa saja dapat mengalami gangguan kesehatan. Anak sangat rentan terhadap kuman penyakit dan kurangnya kepekaan terhadap gejala suatu penyakit merupakan ketakutan tersendiri bagi orang tua. Orang tua merupakan orang awam yang kurang memahami kesehatan. Apabila terjadi gangguan kesehatan terhadap anak maka mereka lebih mempercayakannya kepada pakar atau dokter ahli yang sudah mengetahui lebih banyak tentang kesehatan, tanpa memperdulikan apakah gangguan tersebut masih dalam tingkat rendah atau kronis. Namun dengan kemudahan dengan adanya para pakar atau dokter ahli, terkadang terdapat pula kelemahannya seperti jam kerja (praktek) terbatas dan banyaknya pasien sehingga harus menunggu antrian.

Dalam hal ini, orang tua selaku pemakai jasa lebih membutuhkan seorang pakar yang bisa memudahkan dalam mengdiagnosa penyakit lebih dini agar dapat melakukan pencegahan lebih awal yang sekiranya membutuhkan waktu jika berkonsultasi dengan dokter ahli. Karena hal tersebutlah maka dibutuhkan suatu alat bantu yang dapat mendiagnosa penyakit anak berupa suatu sistem pakar. 
Sistem pakar merupakan salah satu cabang kecerdasan buatan yang mempelajari bagaimana "mengadopsi" cara seorang pakar berfikir dan bernalar dalam menyelesaikan suatu permasalahan, dan membuat suatu keputusan maupun mengambil kesimpulan dari sejumlah fakta yang ada (Muhammad, 2005). Dasar dari sistem pakar adalah bagaimana memindahkan pengetahuan yang dimiliki oleh seorang pakar ke dalam komputer, dan bagaimana membuat keputusan atau mengambil kesimpulan berdasarkan pengetahuan itu.

\subsection{Rumusan Masalah}

Permasalahan yang akan dibahas dalam penulisan tugas akhir ini adalah bagaimana merancang suatu sistem pakar yang dapat digunakan untuk mendiagnosa suatu jenis penyakit demam berdarah berdasarkan gejala yang dirasakan pengguna.

\subsection{Tujuan}

Tujuan dari tugas akhir ini adalah membuat sistem pakar yang memiliki kemampuan untuk mengatasi masalah penyakit pada anak yang mengidap gejala penyakit demam berdarah, dan mampu berpikir cepat dan tepat dalam memberikan solusi dari masalah penyakit anak tersebut yang dapat dikembangkan lebih lanjut dan memberikan kemudahan bagi pemakainya

\subsection{Batasan Masalah}

Dalam penulisan tugas akhir ini pembahasan masalah memiliki batasan pada permasalahan berikut:

1. Data-data penunjang yang digunakan hanya dikhususkan pada ciri-ciri penyakit pada anak yang disebabkan virus dengue.

2. Pembangunan sistem pakar menggunakan kaidah produksi dengan metode inferensi fordward chaining dengan teknik penelusuran data depth first search.

3. Jenis penyakit yang didiagnosa hanya penyakit yang umum terjadi pada anak di daerah tropis, hanya Demam Berdarah ( DB ).

4. Program aplikasi ini menggunakan bahasa pemrograman PHP dan penyimpanan data-data penunjang menggunakan database MySQL.

5. Data-data penunjang penyakit yang digunakan hanya pada usia (kurang dari 10 tahun) saja.

6. Keluaran yang dihasilkan dari prangkat lunak ini adalah jenis penyakit anak

\section{LANDASAN TEORI}

\subsection{Kecerdasan Buatan}

Kecerdasan buatan merupakan bagian dari ilmu pengetahuan komputer yang khusus ditunjukan dalam perancangan otomisasi tingkah laku cerdas dalam sistem kecerdasan komputer. Sistem memperlihatkan sifat-sifat unik yang dihubungkan dengan kecerdasan dalam kelakuan atau tindak-tanduk yang sepenuhnya bisa menirukan beberapa fungsi otak manusia, seperti pengertian bahasa, pengetahuan,pemikiran, pemecahan masalah dan lain sebagainya (Kusumadewi, 2003).

Agar mesin bisa cerdas dan bertindak seperti dan sebaik manusia maka harus diberi bekal pengetahuan dan mempunyai kemampuan untuk menalar. Dua bagian utama yang dibutuhkan untuk kecerdasan buatan:

a. Basis pengetahuan (knowledge base): berisi faktafakta, teori, pemikiran dan hubungan antara satu dengan lainnya.

b. Mesin inferensi (inference engine) : kemampuan menarik kesimpulan berdasarkan pengalaman.

Bagian utama sistem pakar dapat ditunjukkan pada Gambar 2.1

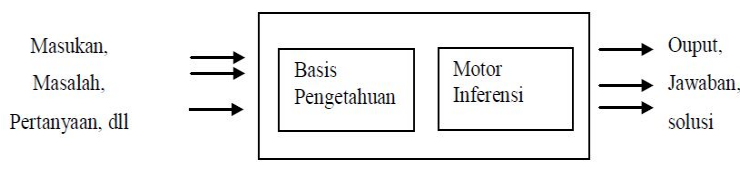

Gambar 2.1 Bagian utama kecerdasan buatan

Implementasi dari kecerdasan buatan saat ini dapat ditemui dalam bidang-bidang antara lain:

1. Logika Fuzzy (Fuzzy Logic) : suatu metode kecerdasan buatan yang banyak terdapat pada alat elektronik dan robot. Dimana alat-alat elektronik atau robot tersebut mampu berpikir dan bertingkah laku sebagaimana layaknya manusia.

2. Komputer Visi (Computer Vision): Suatu metode kecerdasan buatan yang memungkinkan sebuah sistem komputer mengenali gambar sebagai inputnya. Contohnya adalah mengenali dan membaca tulisan yang ada gambarnya.

3. Kecerdasan Buatan (Artificial Intelegence)dalam game:suatu metode kecerdasan buatan yang berguna untuk meniru cara berpikir seorang manusia dalam bermain game. Contohnya adalah program deep blue yang mampu berpikir setara dengan seorangahli dalam bermian catur. 
4. Pengenal Suara (Speech Recognition): suatu metode kecerdasan buatan yang berguna untuk mengenali suara manusia dengan cara dicocokkan dengan acuan yang telah diprogramkan sebelumnya. Contohnya adalah suara dari penggunadapat diterjemahkan menjadi sebuah perintah bagi komputer.

5. Sistem Pakar (Expert System) : suatu metode kecerdasan buatan yang berguna untuk meniru cara berpikir dan penalaran seorang pakar dalam mengambil keputusan berdasarkan situasi yang ada.

\subsection{Sistem Pakar}

Ada beberapa defenisi tentang sistem pakar, antara lain(Kusrini, 2006) :

1. Menurut Durkin: Sistem pakar adalah suatu program komputer yang dirancang untuk memodelkan kemampuan penyelesaian masalah yang dilakukan oleh seorang pakar.

2. Menurut Ignizio: Sistem pakar adalah suatu model dan prosedur yang berkaitan, dalam suatu domain tertentu, yang mana tingkat keahliannya dapat dibandingkan dengan keahlian seorang pakar.

3. Menurut Giarratano dan Riley: Sistem pakar adalah suatu sistem komputer yang bisa menyamai atau meniru kemampuan seorang pakar.

Suatu sistem dikatakan sistem pakar apabila memiliki ciri-ciri sebagai berikut (Kusrini, 2006) :

1. Terbatas pada bidang yang spesifik.

2. Dapat memberikan penalaran untuk data-data yang tidak lengkap dan tidak pasti.

3. Dapat mengemukakan rangkaian alasan yang diberikannya dengan cara yang dapat dipahami.

4. Berdasarkan aturan atau kaidah tertentu.

5. Dirancang untuk dapat dikembangkan secara bertahap.

6. Keluarannya tergantung dari dialog dengan pengguna.

7. Basis pengetahuan dan antarmuka terpisah.

Secara garis besar, banyak keuntungan yang dapat diambil dengan adanya sistem pakar, antara lain(Kusrini. 2006) :

1. Memungkinkan orang awam bisa mengerjakan pekerjaan para ahli.

2. Menyimpan pengetahuan dan keahlian para pakar.

3. Mampu mengambil keahlian para pakar.

4. Memiliki kemampuan untuk mengakses pengetahuan.

5. Meningkatkan kapabilitas sistem komputer.
6. Memiliki kemampuan untuk bekerja dengan informasi yang tidak lengkap dan mengandung ketidakpastian.

7. Sebagai media pelengkap dalam pelatihan.

8. Meningkatkan kapabilitas dalam penyelesaian masalah.

9. Menghemat waktu dalam pengambil keputusan.

Disamping memiliki beberapa keuntungan, sistem pakar juga memiliki beberapakelemahan, antara lain:

1. Untuk sistem pakar yang sangat komplek, biaya yang diperlukan untuk membuat dan memeliharanya sangat mahal.

2. Sedikitnya ketersediaan pakar dibidangnya sehingga sistem pakar sulit dibuat atau dikembangkan.

3. Sistem pakar tidak $100 \%$ bernilai benar.

Gambar 2.2 berikut ini merupakan struktur dari sistem pakar(Kusrini, 2006).

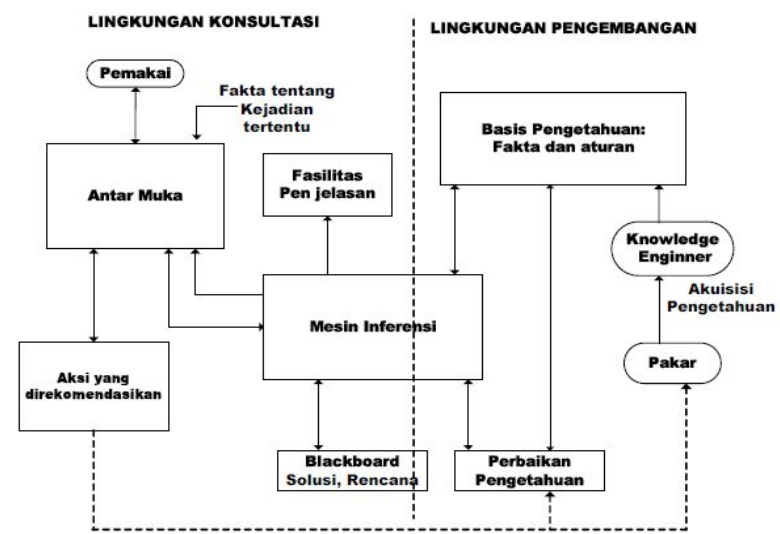

Gambar 2.2 Penerapan struktur sistem pakar

\section{Keterangan gambar :}

_ _ _ : pemisah antara lingkuangan konsultasi dengan lingkungan pengembang.

$\longleftrightarrow$ : komunikasi dua arah

$\longrightarrow$ : langsung

-------> : tidak langsung

\subsection{Representasi pengetahuan}

Representasi pengetahuan merupakan metode yang digunakan untuk mengkodekan pengetahuan dalam sebuah sistem pakar(Kusrini, 2008). Representasi pengetahuan dimaksudkan untuk menangkap sifat-sifat penting masalah dan membuat informasi itu dapat diakses oleh prosedur pemecahan masalah. Terdapat 5 teknik yang telah dibuktikan efektif untuk representasi pengetahuan (Kusrini, 2008) : 
1. Jaringan Semantik

Jaringan semantik merupakan representasi AI (Artificial Intelegence) yang digunakan untuk informasi yang proporsisional. Proposisi adalah kalimat yang bernilai benar atau salah. Proposisi adalah bentuk pengetahuan deklaratif karena menyatakan fakta. Dalam matematika, istilah jaringan semantik merupakan suatu label atau graph berarah. Struktur dan jaringan semantik ditunjukkan secara grafik yang terdiri dari simpuldan busuryang menghubungkannya. Simpul menyatakan objek dan busur sebagai tautan. Tautan digunakan untuk menyatakan hubungan sedangkan simpul biasanya digunakan untuk merepresentasikan secara objek.

2. Frame

Frame merupakan tipe skema yang sering digunakan dalam aplikasi AI. Frame berupa kumpulan-kumpulan slot-slot yang merupakan atribut untuk mendeskripsikan pengetahuanpengetahuan yang termuat dalam slot dapat berupa kejadian, lokasi, situasi ataupun elemen-elemen lain. Frame digunakan untuk representasi pengetahuan deklaratif. Frame memuat deskripsi sebuah objek dengan menggunakan tabulasi yang berhubungan dengan objek sehingga frame mengelompokkan atribut sebuah objek. Dengan demikian frame dapat membantu menirukan cara mengorganisasi informasi sebuah objek menjadi kumpulan data.

3. Script

Script menyerupai frame dengan penambahan informasi, termasuk tentang harapan rentetan kejadian dan tujuan serta perencanaan yang melibatkan para aktornya. Ini merupakan representasi terbaik yang menggambarkan harapan konsep yang dijalankan untuk pemrosesan. Script juga merupakan pendekatan yang telah terbukti sebagai alat yang bernilai untuk membangun pengetahuan dan pemahaman ke dalam sistem computer. Jika frame menggambarkan objek sedangkan script menggambarkan urutan kejadian.

4. Logika

Selain dengan script, frame dan jaringan semantik, pengetahuan juga bisa direpresentasikan denga menggunakan symbol logika, yang studi aturannya merupakan bagian dari penalaran eksak. Bagian yang paling penting dari penalaran ini adalah mengambil kesimpulan dari premis. Aplikasi komputer untuk melakukan penalaran telah dihasilkan dalam logika pemrograman dan pengembangan bahasa dasar logika seperti prolog. Logika juga sangat penting dalam sistem pakar sebagai mesin penarik kesimpulan dari fakta ke kesimpulan.

5. Kaidah Produksi

Konsep dari sistem produksi atau kaidah produksi telah diperkenalkan oleh Post tahun 1943. Konsep ini kemudian ditampilkan kembali dalam konteks proses bahasa alami dalam kaidah-kaidah penulisan dari Chomsky pada tahun 1957. Aturan produksi yang diusulkan adalah untuk memodelkan penyelesaian permasalahan tingkah laku manusia oleh Newll dan Simon pada tahun 1972. Kaidah produksi menjadi acuan yang sangat sering digunakan oleh sistem inferensi, sistem berbasis kaidah, dan dalam kasus penyelesaian masalah tingkah laku manusia ataupun dalam produksi sederhana.

\subsection{Pohon (TREE)}

Suatu pohon (tree) adalah suatu hierarki struktur yang terdiri dari node (simpul) yang menyimpan informasi atau pengetahuan dan cabang yang menghubungkan node. Dengan berorientasi pada tree, akar simpul adalah simpul yang tertinggi dalam hierarki dan daun adalah paling bawah. Tree dapat dianggap sebagai suatu tipe khusus dari jaringan semantik yang setiap simpulnya, kecuali akar pasti mempunyai satu simpul orang tua dan mempunyai nol atau lebih simpul anak. Gambar 2.5 menunjukkan pohon biner yang mempunyai 0,1 atau 2 cabang per simpul.

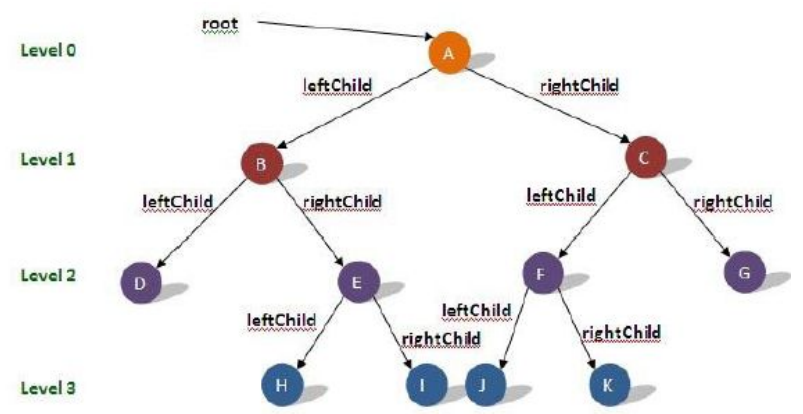

Gambar 2.3Binary tree yang mempunyai 0, 1 atau 2 cabang per node

\subsection{Pediatric}

Pediatric berasal dari bahasa yunani, yaitu pedos yang berarti anak dan iatrica yang berarti pengobatan. Arti bahasa Indonesia yang sebenarnya ialah ilmu pengobatan anak dan pengertian ini lebih tepat dari pada ilmu penyakit anak yang ternyata masih sering dipakai (Gilbert, 1986).

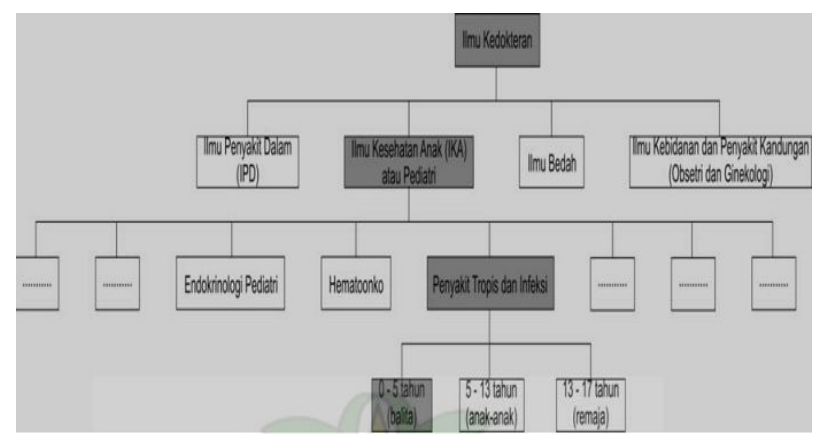

Gambar 2.4 gambar diagram penyakit anak

\subsection{Bahasa Pemograman WEB}


Saat ini banayak sekalai bahasa pemograman diantaranya : PHP, CSS, JavaScript, Jquery, Dan lain sebagainya.

\subsubsection{PHP}

PHP merupakan singkatan dari Pretext HyperProcessoryang merupakan bahasa berbentuk skrip yang ditempatkan pada server dan diproses di server. Hasilnya kemudian dikirimkan ke browser klien (Nugroho, Bunafit, 2004).

Contoh script php adalah sebagai berikut :

$<$ html $>$

$<$ head $>$

$<$ title $>$ program hello world $</$ title $>$

$</$ head $>$

$<$ body $>$

$<$ ?php

echo "hello world";

?>

$</$ body $>$

$</$ html $>$

PHP adalah bahasa open source yang dapat digunakan di berbagai mesin (Linux, UNIX, Macintosh, dan Windows) dan dapat dijalankan secara runtime melalui konsol serta juga dapat menjalankan perintahperintah sistem.

\subsubsection{MySQL}

MySQL adalah sebuah perangkat lunak sistem manajemen basis data SQL atau DBMS yang multithread, multi-user dengan sekitar 6 juta instalasi di seluruh dunia.MySQL AB membuat MySQL tersedia sebagai perangkat lunak gratis di bawah lisensi GNU General Public Licence (GPL).Tetapi mereka juga menjual di bawah lisensi komersial untuk kasus-kasus di mana penggunaannya tida cocok dengan pengunaan GPL.

Contoh query sql adalah sebagai berikut :

INSERT INTO table_name

( field1, field2,..fieldN )

VALUES

( value1, value2,...valueN );

MySQL menawarkan berbagai keunggulan dibandingkan basis data yang lain, seperti(Hirin A.M dan Virgi, 2011) :

1. Mampu menangani jutaan pengguna dalam waktu yang bersamaan.

2. Mampu menampung lebih dari 50 juta record.
3. Sangat cepat mengeksekusi perintah.

4. Memiliki user privilege system yang mudah dan efisien.

5. MySQL menyediakan dukungan open source.

\subsection{Jenis Penyakit}

\subsubsection{Demam Dengue}

Demam dengue merupakan penyakit demam stadium awal dari penyakit demam berdarah. Tetapi sangat berbahaya jika tidak ditanggulangi secara cepat.

Dari beberapa pakar mengatakan gejala demam dengue ini hanya seperti penyakit demam biasa, tetapi $\mathrm{m}$ empunyai gejala yang berbeda, contoh dari gejala tersebu $\mathrm{t}$ adalah depresi dan lain sebagainya

\subsubsection{Demam Berdarah Dengue}

Demam Berdarah Dengue adalah Penyakit demam akut, terutama menyerang anak yang disertai dengan manifestasi perdarahan dan bertendesi menimbulkan shock yang dapat menyebabkan kematian serta sering menimbulkan kejadian luar biasa atau wabah.

Demam Berdarah Dengue merupakan penyakit yang disebarkan oleh nyamuk Aedes Aegypty yang ditand ai dengan demam mendadak, tinggi, dan terus-menerus y ang berlangsung selama 2-7 hari disertai dengan tanda pe rdarahan di kulit (petechiae), lebam (ekimosis), pendarah an gusi, epistaksis, muntah darah (hematemesis). (Ilmu P enyakit Dalam 1996).

\subsubsection{Syok Syndrom Dengue}

Syok sindrom merupakan penyakit demam berd arah stadium akhir dari penyakit demam berdarah yang $\mathrm{s}$ angat berbahaya jika tidak ditanggulangi dengan cepat. $\mathrm{P}$ enyakit syok sindrom mempunyai gejala yang sangat ber bahaya contoh gejala tersebut adalah demam tinggi, nadi terasa lembut, kejang dan kesadaran menurun

\section{PERANCANGAN SISTEM}

\subsection{Analisis Sistem}

Analisis sistem merupakan salah satu proses yang harus dilakukan dalam melakukan perancangan suatu perangkat lunak. Karena di dalam tahap ini merupakan tahap penguraian dari suatu sistem aplikasi yang utuh kedalam bagian komponennya.

Perancangan sistem pakar untuk mendiagnosa $\mathrm{s}$ ecara dini penyakit pada anak berbasis web memanfaatka $\mathrm{n}$ keahlian seorang pakar untuk menganalisa suatu gejala penyakit yang dirasakan oleh pengguna untuk menemuka $\mathrm{n}$ hasil diagnosa untuk mendapatkan penyebab penyakit $\mathrm{b}$ erikut penanganannya

\subsection{Analisis Kebutuhan}

Sistem yang dibuat seringkali tidak sesuai dengan keinginan dari pengguna sistem yang memungkinkan terjadi kesalahan dan ketidaksepahaman. Hal ini biasa terjadi jika dalam pembuatan sebuah sistem tidak diawali dengan analisis kebutuhan yang mendasar dan rinci. Analisis kebutuhan dapat dilakukan melalui wawancara dengan pihak-pihak terkait dan pengamatan dari lingkungan dimana sistem akan dibangun.

Setelah melakukan wawancara dan pengamatan 
terhadap kebutuhan pengguna, diharapkan sistem pakar yang dibuat dapat:

1. Membantu pekerjaan pakar dalam mendiagnosis penyakit demam berdarah, karena keahlian pakar direpresentasikan ke dalam sistem pakar sebagai asisten dari seorang pakar. Sedangkan yang bertugas mengelola basis pengetahuan sistem pakar ini admin.

2. Mempermudah pengguna bukan pakar dalam mendia gnosis penyakit demam berdarah selayaknya seorang pakar.

\subsubsection{Kebutuhan Fungsional}

Mengacu kepada kebutuhan pengguna dalam mendiagnosis penyakit demam berdarah, maka fungsi yang ada dari sistem pakar ini dikelompokkan menjadi :

1. Halaman Home

Merupakan tampilam awal dari aplikasi sistem pakar penyakit demam berdarah. Dimana tampilan awal yang akan dibuka oleh user.

2. Diagnosa

Merupakan fitur yang berfungsi melakukan konsultasi penyakit demam berdarah. Dimana pengguna menjawab pertanyaan yang ditampilkan oleh sistem berupa gejala demam berdarah.

3. Mengelola Basis Pengetahuan

Merupakan fitur yang digunakan di halaman admin untuk mengelola basis pengetahuan berupa data penyakti, data gejala dan data relasi gejala-penyakit.

4. Mengelola Data User

Merupakan fitur dihalaman admin untuk mengelola data dari pengguna.

5. Cara Kerja Sistem

Merupakan fitur dihalaman user yang berfungsi untuk memberitahukan bagaimana cara menggunakan aplikasi sistem pakar penyakit demam berdarah.

6. Tentang Pakar

Merupakan fitur yang berguna untuk memberitahukan pengertian tentang sistem pakar

7. Log out

Merupakan fitur untuk keluar dari aplikasi sistem pak ar.

\subsubsection{Tabel Akuisisi Pengetahuan}

Cara representasi pengetahuan yang tepat diperlukan untuk membuat suatu sistem pakar agar dapat melakukan penalaran yang baik. Perancangan akuisisi pengetahuan ini dimulai dengan membuat tabel penyakit, gejala, dan penangan. Tabel 3.1 berikut ini merupakan tabel akuisisi dari sistem pakar yang akan dibangun.

Table 3.1 Akuisisi Pengetahuan

\begin{tabular}{|c|c|c|}
\hline Demam Dengue & $\begin{array}{l}\text { 1. nyeri kepala } \\
\text { 2.sakit tulang belakang } \\
\text { 3. perasaan letih } \\
\text { 4. menggigil } \\
\text { 5. muka kemerahan } \\
\text { 6. Demam Tinggi } \\
\text { 7. kejang } \\
\text { 8. nyeri tenggorokan } \\
\text { 9. nyeri perut } \\
\text { 10. depresi } \\
\text { 11. diare }\end{array}$ & $\begin{array}{l}\text { 1. } \begin{array}{l}\text { istirahat yang } \\
\text { cukup }\end{array} \\
\text { 2. memberikan } \\
\text { obat sesuai } \\
\text { dengan gejala, } \\
\text { misal obat } \\
\text { untuk penurun } \\
\text { panas } \\
\text { parasetamol, } \\
\text { dan untuk sakit } \\
\text { perut Spasman } \\
\text { (hnya tersedia } \\
\text { d apotik) } \\
\text { banyak minum } \\
\text { Segera } \\
\text { membawa anak } \\
\text { periksa } \\
\text { dokter }\end{array}$ \\
\hline $\begin{array}{l}\text { Demam Berdarah } \\
\text { Den gue }\end{array}$ & $\begin{array}{l}\text { 1. demam tinggi } \\
\text { 2. mimisan } \\
\text { 3.pendarahan pada } \\
\text { gusi } \\
\text { 4. muka kemerahan } \\
\text { 5. sakit kepala } \\
\text { 6. muntah } \\
\text { 7. nyeri pada otot } \\
\text { 8. nyeri tenggorokan } \\
\text { 9.nyeri diseluruh } \\
\text { bagian perut } \\
\text { 10.kesadaran menurun } \\
\text { 11. kejang } \\
\text { 12. mual } \\
\text { 13.bintik merah pada } \\
\text { kulit } \\
\text { 14.nyeri pada iga } \\
\text { sebelah kanan } \\
\text { 15. batuk } \\
\text { 16. nyeri sendi } \\
\text { 17.nadi berdenyut } \\
\text { cepat } \\
\text { 18. kaki dingin } \\
\text { 19. tangan dingin } \\
\text { 20. kulit lembab }\end{array}$ & $\begin{array}{l}\text { 1. } \text { Istirahat yang } \\
\text { cukup } \\
\text { 2. Memberikan obat } \\
\text { sesuai dengan } \\
\text { gejala, misal } \\
\text { obat untuk } \\
\text { penurun panas } \\
\text { parasetamol, } \\
\text { dan untuk sakit } \\
\text { perut Spasman } \\
\text { (hnya tersedia d } \\
\text { apotik) } \\
\text { 3. Banyak minum } \\
\text { 4. Segera } \\
\text { membawa anak } \\
\text { periksa ke } \\
\text { dokter }\end{array}$ \\
\hline $\begin{array}{ll}\text { Syok } & \text { Syndrom } \\
\text { Dengue } & \end{array}$ & $\begin{array}{ll}\text { 1. } & \begin{array}{l}\text { Selalu merasa } \\
\text { gelisah }\end{array} \\
\text { 2. } & \text { Nafas cepat } \\
\text { 3. } & \text { Nadi terasa } \\
\text { lembut } \\
\text { 4. }\end{array}$ & 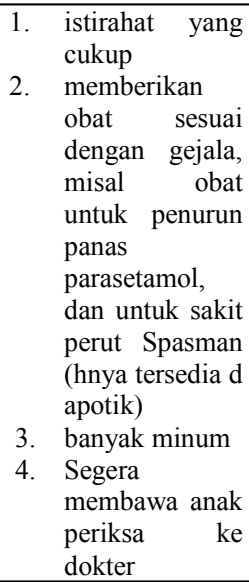 \\
\hline
\end{tabular}

\subsubsection{Pohon Keputusan}

Pohon keputusan merupakan gambaran dari urutan proses yang terjadi dalam sistem, pohon keputusan melakukan proses pengambilan keputusan dan penelusuran penyakit demam berdarah yang didasarkan pada tabel gejala. Proses pengambilan keputusan menggunakan metode forward chaining. Gambar 3.1 berikut ini merupakan gambar dari pohon keputusan dari aplikasi sistem pakar penyakit demam berdarah yang akan dibangun. 


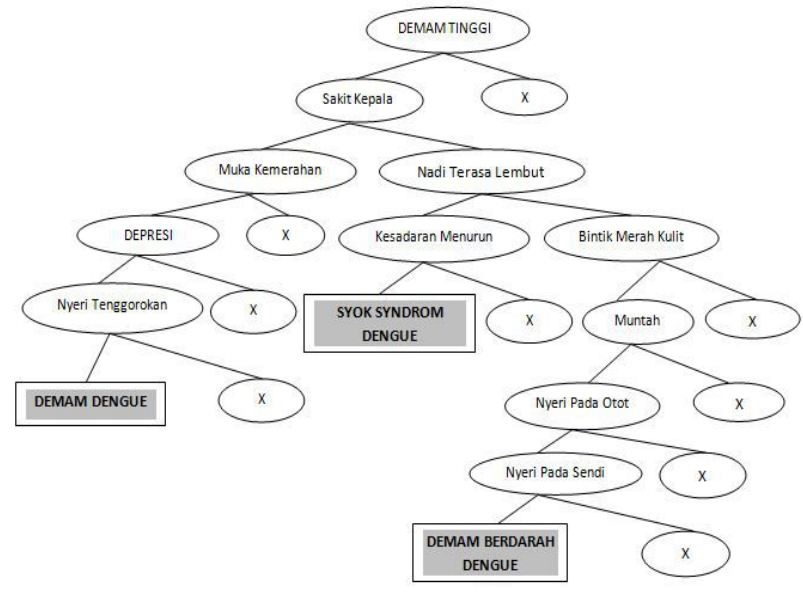

Gambar 3.1 Pohon keputusan

Keterangan :

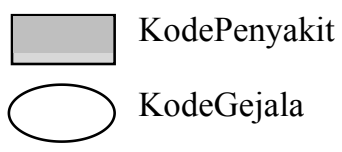

\subsubsection{Perancangan Representasi Pengetahuan}

Representasi pengetahuan dimaksudkan untuk mengorganisasikan basis pengetahuan dalam bentuk dan format tertentu untuk bisa dimengerti oleh komputer. Basis pengetahuan merupakan sekumpulan pengetahuan yang dihubungkan dengan sejumlah permasalahan yang digunakan dalam sistem kecerdasan buatan. Basis pengetahuan ini merupakan analisa data yang akan digunakan dalam pembangunan sistem. Basis pengetahuan digunakan untuk penarikan kesimpulan yang merupakan hasil dari proses pelacakan. Pada perancangan basis pengetahuan sistem pakar ini konklusi adalah jenis penyakit dan premis adalah gejala, sehingga bentuk pernyataannya adalah MAKA [konklusi] JIKA [premis].pada perancangan basis pengetahuan sistem pakar ini konklusu adalah jenis penyakit dan premis adalah gejala, sehingga bentuk pernyataannya adalah MAKA [penyakit] JIKA [gejala]

Pada sistem pakar ini dalam satu kaidah dapat memiliki lebih dari satu gejala. Dan gejala-gejala tersebut dihubungkan dengan menggunkan operator logika DAN. Adapun bentuk pernyataannya adalah :

MAKA [ Penyakit ]

JIKA [ Gejala 1] DAN [ Gejala 2 ] DAN [Gejala 3]

Aturan kaidah produksi tersebut dapat juga dijelaskan dalam bentuk Tabel 3.5 sebagai berikut :

Tabel 3.2 Kaidah produksi

\begin{tabular}{|c|l|}
\hline No & \multicolumn{1}{|c|}{ Aturan } \\
\hline 1 & $\begin{array}{l}\text { R1 : IF G1 AND G5 AND G9 AND G10 } \\
\text { AND G11 THEN P1 }\end{array}$ \\
\hline 2 & R2 : IF G5 AND G4 THEN P3 \\
\hline 3 & $\begin{array}{l}\text { R3 : IF G1 AND G3 AND G6 AND G7 AND } \\
\text { G8 THEN P3 }\end{array}$ \\
\hline
\end{tabular}

Bentuk flowchart dari mesin inferensi ini adalah sebagai berikut :

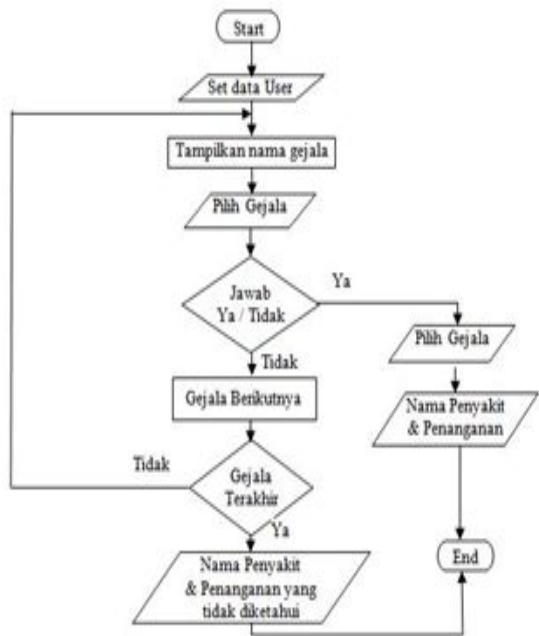

Gambar 3.2 Flowchart

Contoh penelusuran dari mesin inferensi ini adalah sebagai berikut

Pakar : Apakah anda mengalami G001 (sakit Kepala)? Pengguna : Ya

Pakar : Apakah anda mengalami G003 (perasaan lelah)? Pengguna : Ya

Pakar : Apakah anda mengalami G002 (sakit tulang belakang)?

Pengguna : Ya

Pakar : Apakah anda mengalami G006 (demam tinggi)? Pengguna : Ya

Pakar : Jenis Penyakit Anda adalah P001(demam dengu e)

\subsubsection{Perancangan Data Flow Diagram (DFD)}

Data flow diagram merupakan diagram aliran data yang menggambarkan bagaimana data diproses oleh sistem. Selain itu Data flow diagram (DFD) menggambarkan notasi- notasi aliran data di dalam sistem.

Proses perancangan dimulai dengan pembuatan bagan alir sistem atau yang disebut dengan Diagram Konteks. Diagram konteks menggambarkan suatu sistem secara umum.

Diagram konteks ini juga menggambarkan bahwa Perancangan Sistem Pakar Untuk Mendiagnosa Penyakit didaerah tropis pada anak berbasis web mempunyai dua pengguna sistem yaitu : Admin dan User. Admin adalah orang yang mempunyai kewenangan penuh atas sistem, bertugas mengelola hak akses pada sistem, dan menghasilkan diagnosa penyakit. Sedangkan User adalah orang yang dapat mengakses sistem dengan dapat melihat data penyakit dan gejala tanpa dapat mengubah atau memanipulasi data dan dapat mendapatkan hasil diagnosa penyakit. Diagram konteks sistem pakar penyakit pada anak dapat dilihat pada gambar di bawah ini : 


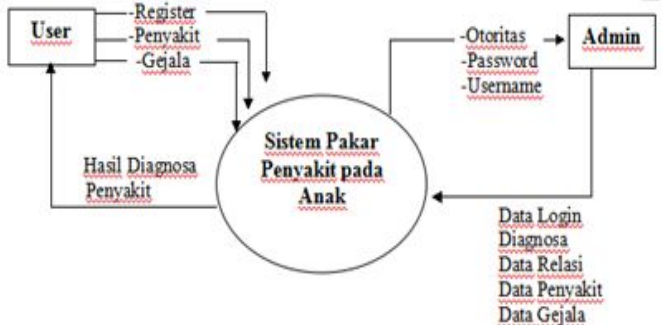

Gambar 3.3 Diagram Konteks

Diagram Konteks di atas dapat dijabarkan menjadi lebih rinci lagi yang disebut DFD Level 0 .

Dalam DFD Level 0, admin mempunyai otoritas terhadap proses login pakar dengan mengatur data login berupa username dan password, yang tersimpan dalam datastore Login. Admin juga dapat mengatur diagnosa dalam sistem melalui proses pengolahan data. Data tersebut berupa penyakit, gejala dan relasi yang disimpan ke dalam datastore penyakit, datastore gejala, dan datastore relasi, untuk selanjutnya dipakai dalam proses diagnose penyakit. User mengakses data penyakit dan gejala, dan dapat berkonsultasi dalam proses diagnosa penyakit. Setelah user mendapatkan hasil diagnosa penyakit, kemudian sistem menyimpannya dalam datastore diagnosa.

Pada aplikasi ini, dekomposisi diagram ditunjukkan pada gambar berikut :

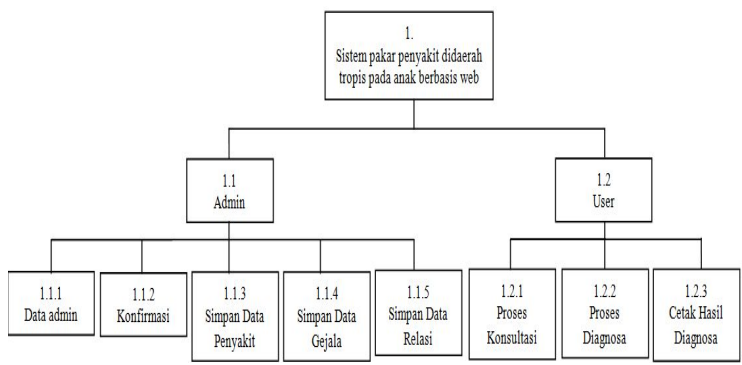

Gambar 3.4 Dekomposisi diagram

\subsubsection{Entiity Relationship Diagram (ER Diagram)}

Menurut salah satu para ahli, Brady dan Loonam (2010), Entity Relationship Diagram (ERD) merupakan teknik yang digunakan untuk memodelkan kebutuhan data dari suatu organisasi, biasanya oleh System Analys dalam tahap analisis persyaratan proyek pengembangan system. ER_diagram dapat ditunjukkan pada gambar berikut :

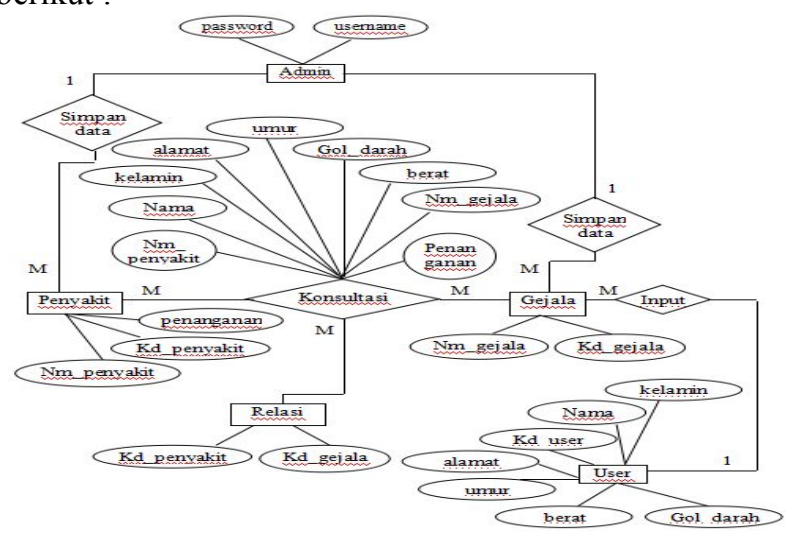

Gambar 3.5 ER-Diagram

\section{IMPLEMENTASI DAN PENGUJIAN}

\subsection{Implementasi}

Tahap implementasi sistem merupakan tahap menerjemahkan perancangan berdasarkan hasil analisa dalam bahasa yang dapat dimengerti oleh mesin serta penerapan perangkat lunak pada keadaan yang sesungguhnya.

\subsection{Implementasi Antarmuka}

Implementasi antarmuka menggambarkan tampilan dari aplikasi yang dibangun yaitu implementasi antarmuka sistem pakar diagnosa penyakit didaerah tropis pada anak berbasis web. Tampilan menu-menu antarmuka ditunjukkan oleh Gambar 4.1

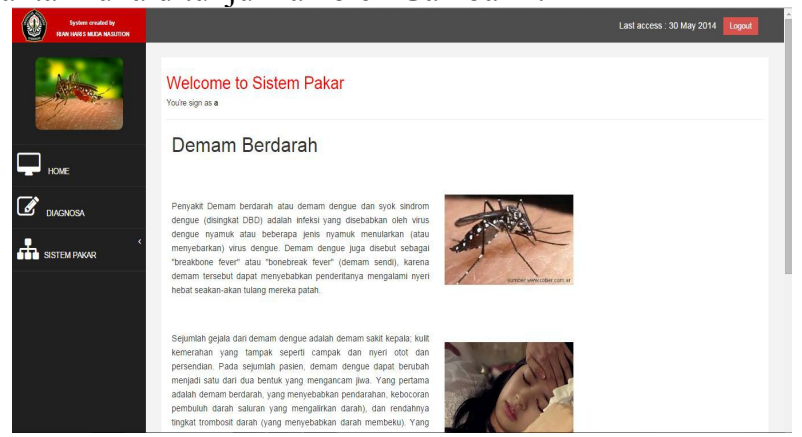

Gambar 4.1 Tampilan menu utama

Tampilan antarmuka halaman diagnosa ditunjukkan pada Gambar 4.2

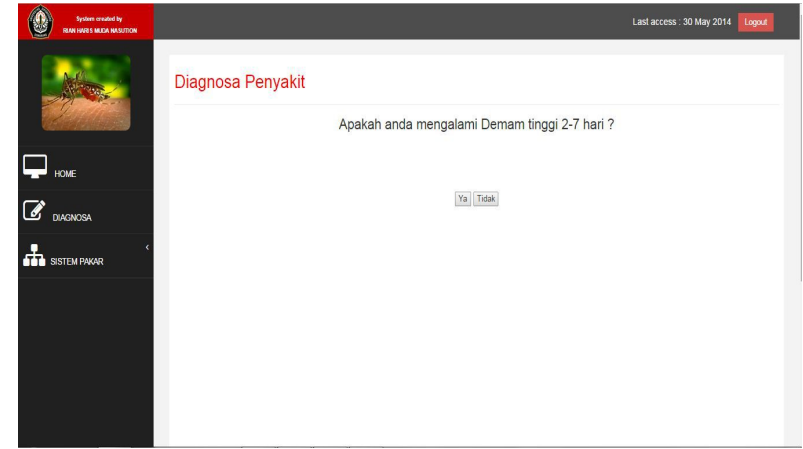

Gambar 4.2 Tampilan menu diagnosa

Tampilan antarmuka hasil diagnosa demam dengue ditunjukkan oleh Gambar 4.3

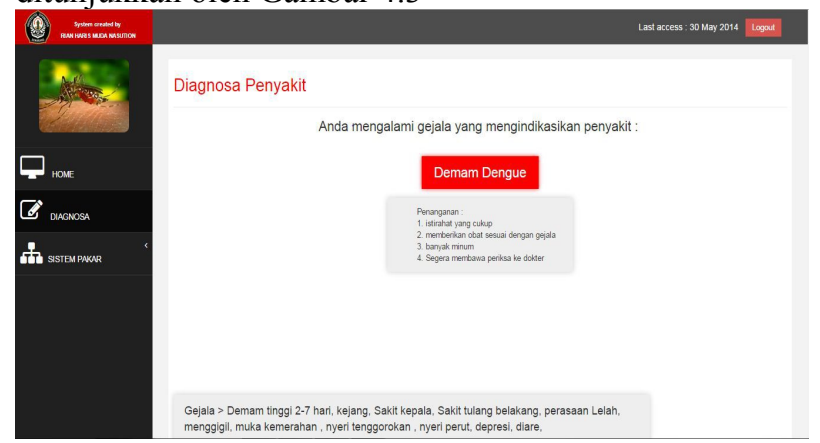

Gambar 4.3 Tampilan menu hasil diagnosa demam dengue 
Tampilan hasil diagnosa demam berdarah dengue ditunjukkan oleh Gambar 4.4

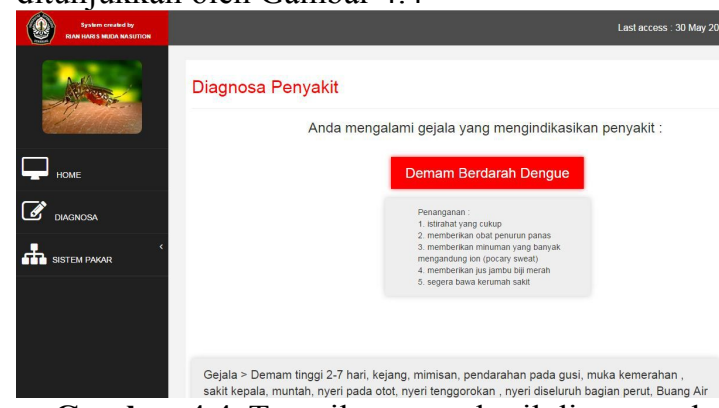

Gambar 4.4 Tampilan menu hasil diagnosa demam berdarah dengue

Tampilan antarmuka hasil diagnosa syok sindrom dengue ditunjukkan oleh Gambar 4.5

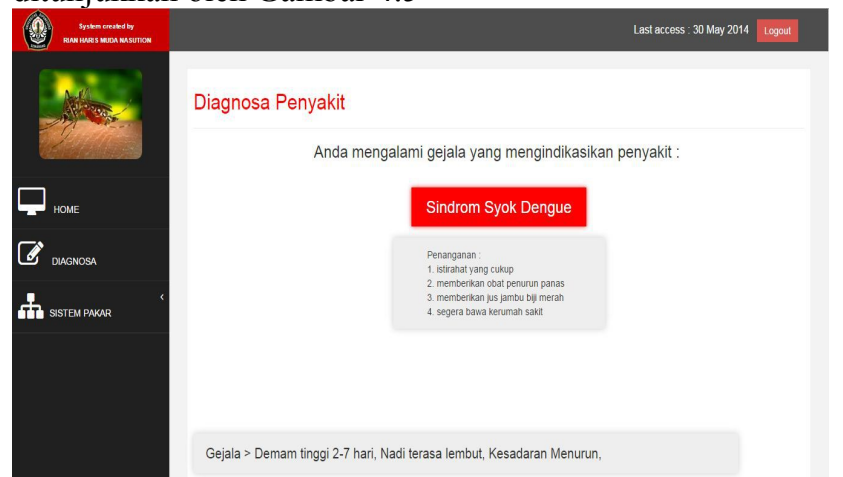

Gambar 4.5 Tampilan hasil diagnosa Syok Sindrom Dengue

Tampilan antarmuka tentang pakar ditunjukkan oleh Gambar 4.6

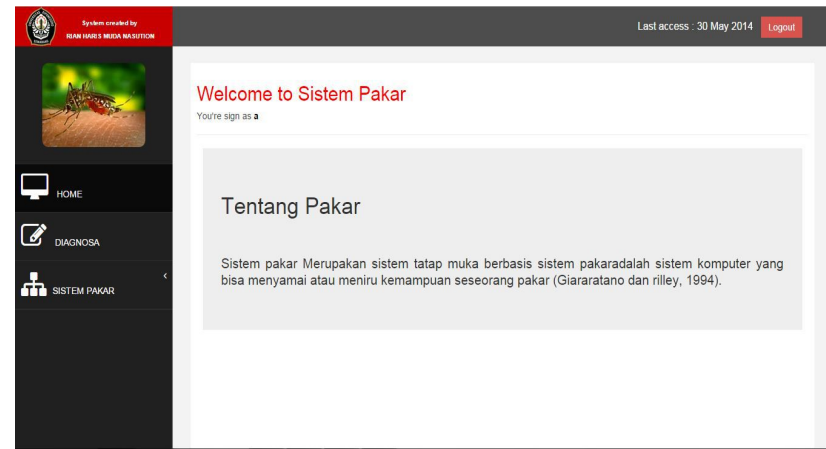

Gambar 4.6 Tampilan menu tentang pakar

Tampilan antarmuka cara kerja sistem pakar ditunjukkan oleh Gambar 4.7

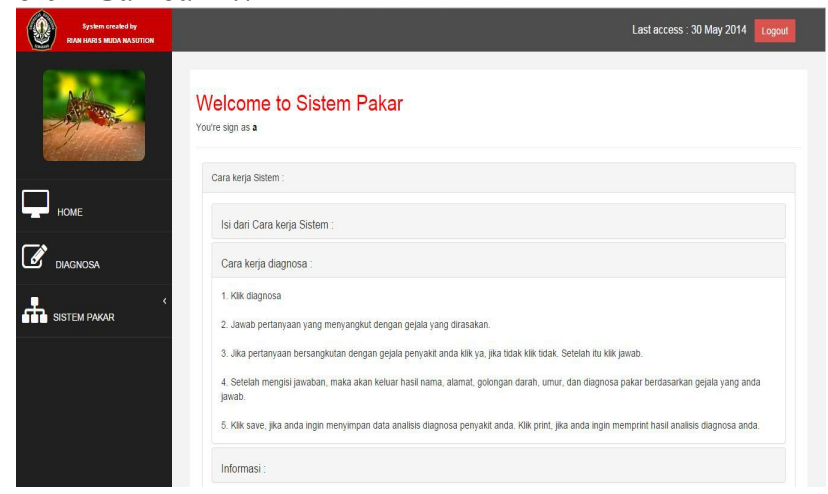

Gambar 4.7 Tampilan menu cara kerja sistem

Tampilan antarmuka halaman pakar/admin ditunjukkan oleh Gambar 4.8

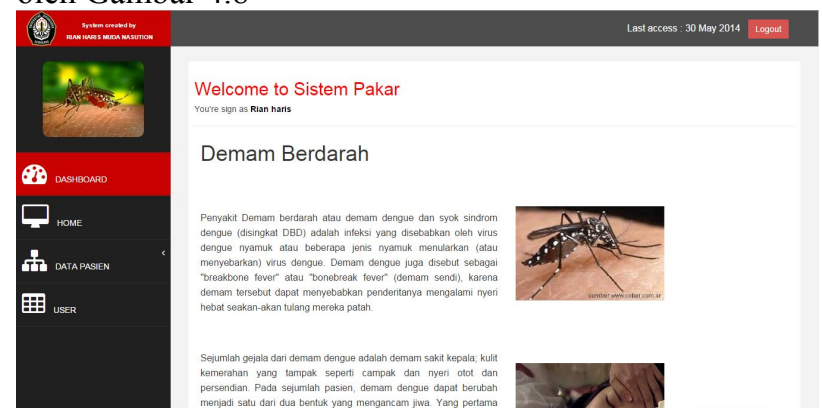

Gambar 4.8 Tampilan menu home

Tampilan antarmuka menu dan gejala ditunjukkan oleh Gambar 4.9

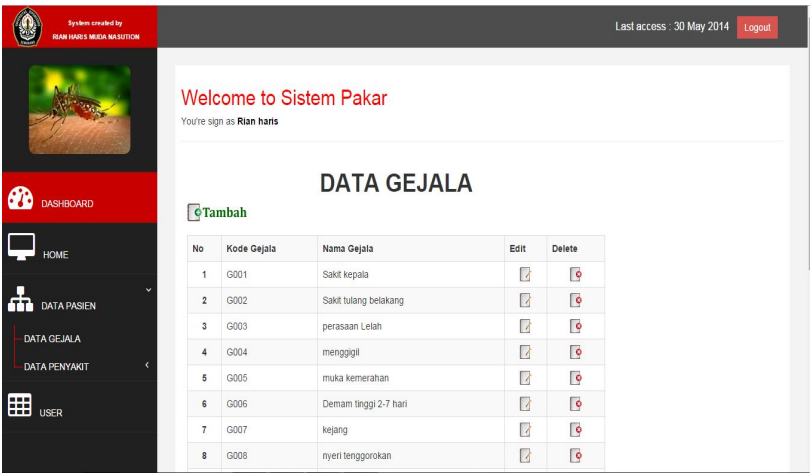

Gambar 4.9 Tampilan menu data gejala

Tampilan antarmuka menu data penyakit ditunjukkan oleh Gambar 4.10

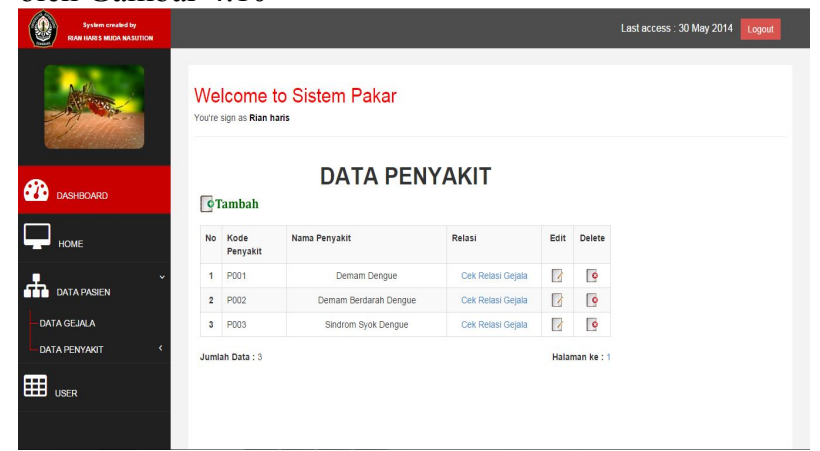

Gambar 4.10 Tampilan menu data penyakit

Tampilan antarmuka menu relasi gejala demam dengue ditunjukkan oleh Gambar 4.11

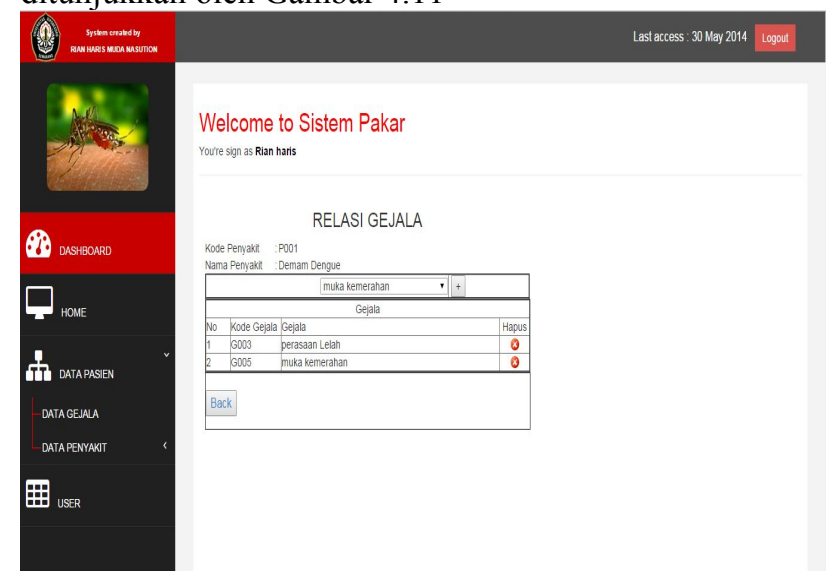

Gambar 4.11 Tampilan menu relasi gejala demam dengue 
Tampilan antarmuka menu relasi gejala demam dengue ditunjukkan oleh Gambar 4.12

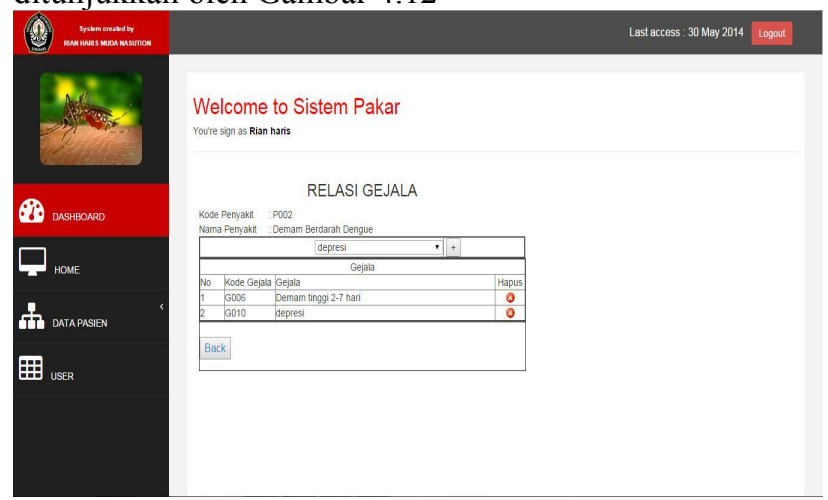

Gambar 4.12 Tampilan menu relasi gejala demam berdarah dengue

Tampilan antarmuka menu relasi gejala demam dengue ditunjukkan oleh Gambar 4.13

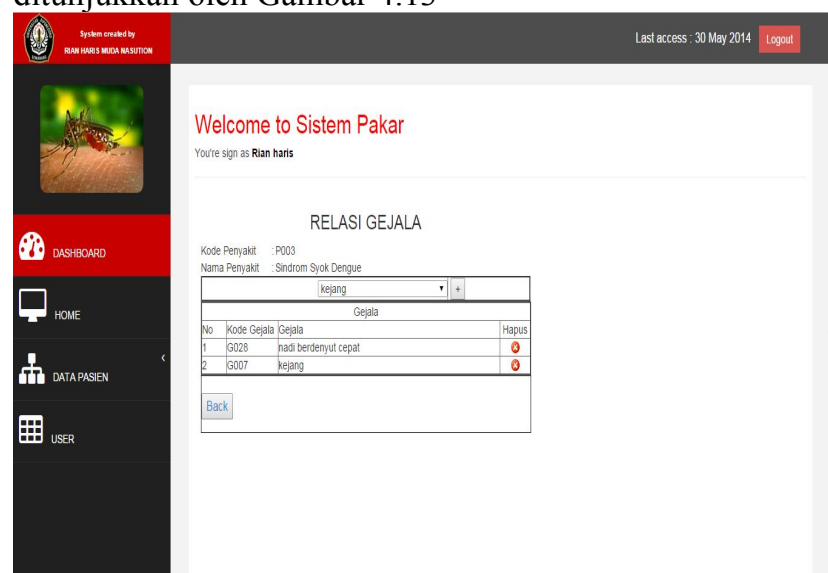

Gambar 4.13 Tampilan menu relasi gejala syok syndrom dengue

Tampilan antarmuka menu relasi gejala demam dengue ditunjukkan oleh Gambar 4.14

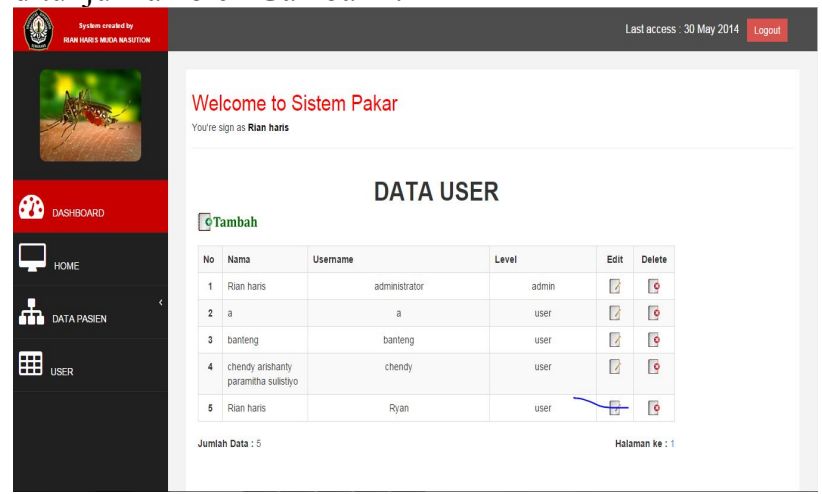

Gambar 4.14 Tampilan menu data user.

\subsection{Kesimpulan Hasil Pengujian Alpha}

Berdasarkan hasil pengujian alpha yang telah dilakukan dapat ditarik kesimpulan bahwa aplikasi sudah berjalan cukup maksimal, tetapi tidak menutup kemungkinan dapat terjadi kesalahan pada suatu saat aplikasi digunakan. Sehingga membutuhkan proses maintenance untuk lebih mengetahui kekurangan dari aplikasi.

\subsection{Kasus dan Hasil Pengujian Betha}

Pengujian betha merupakan pengujian yang dilakukan secara objektif dimana aplikasi diuji secara langsung ke lapangan, yaitu dengan membuat kuisioner yang ditujukan kepada pengguna aplikasi sistem pakar penyakit didaerah tropis pada anak berbasis web yaitu pakar dan pengguna

Kuisioner disebar kepada 20 orang pengguna yang merupakan Mahasiswa koas, Mahasiswa sistem komputer, masyarakat awam, yaitu sebagai pengguna aplikasi sistem pakar Penyakit didaerah tropis pada anak berbasis web.

Kuisioner ini terdiri dari 6 pertanyaan dengan menggunakan tujuh jawaban pilihan yang mewakili dari tujuan akhir yang ingin tercapai dalam pembangunan sistem pakar penyakit didaerah tropis pada anak berbasis web.Pertanyaan ini diajukan kepada pengguna.

Daftar pertanyaan yang diberikan untuk pengguna adalah sebagai berikut :

1. Apakah aplikasi sistem pakar yang dibangun mudah digunakan?

Sangat mudah digunakan Cukup sulit digunakan

Mudah digunakan Sulit digunakan

Cukup mudah digunakan Sangat sulit digunakan

Biasa-biasa saja

2. Apakah aplikasi sistem pakar yang dibangun mudah untuk dipelajari?

Sangat mudah dipelajari

Cukup sulit dipelajari

Mudah dipelajari

Cukup mudah dipelajari dipelajari

Biasa-biasa saja

3. Apakah tampilan antarmuka dari aplikasi sistem pakar terlihat menarik?
Sangat menarik
Kurang menarik
Menarik
Tidak menarik
Cukup menarik
Sangat tidak menarik

Biasa-biasa saja

4. Apakah aplikasi sistem pakar ini dapat membantu dalam mengidentifikasi penyakit demam berdarah ?

Sangat membantu Kurang membantu Membantu

Tidak membantu

Cukup membantu Sangat tidak membantu

Biasa-biasa saja

5. Apakah gejala dan penyakit pada aplikasi ini sesuai dengan kenyataan?

$\begin{array}{ll}\text { Sangat sesuai } & \text { Biasa-biasa saja } \\ \text { Sesuai } & \text { Kurang sesuai } \\ \text { Cukup sesuai } & \text { Tidak sesuai }\end{array}$

Sangat tidak sesuai

6. Apakah hasil kesimpulan dan informasi aplikasi sistem pakar ini akurat?

Sangat akurat

Akurat

Kurang akurat

Tidak akurat 
Berdasarkan data hasil kuisioner, dapat dicari prosentase masing-masing jawaban dengan menggunakan rumus : $\mathrm{Y}=\mathrm{P} / \mathrm{Q} * 100 \%$.

Keterangan $: \mathrm{P}=$ Banyaknya jawaban tiap pertanyaan

$$
\begin{aligned}
& \mathrm{Q}=\text { Jumlah responden } \\
& \mathrm{Y}=\text { Nilai prosentase }
\end{aligned}
$$

Jawaban pelanggan tentang pertanyaan-pertanyaan yang diajukan adalah :

1. Apakah aplikasi sistem pakar yang dibangun mudah digunakan?

Tabel 4.1 Hasil Prosentasi aplikasi mudah digunakan

\begin{tabular}{|l|c|c|}
\hline \multicolumn{1}{|c|}{ Jawaban } & $\begin{array}{c}\text { Jumlah } \\
\text { Responden }\end{array}$ & $\begin{array}{c}\text { Prosentase } \\
(\mathbf{\%})\end{array}$ \\
\hline $\begin{array}{l}\text { Sangat mudah } \\
\text { digunakan }\end{array}$ & 3 & $15,00 \%$ \\
\hline Mudah digunakan & 14 & $70,00 \%$ \\
\hline $\begin{array}{l}\text { Cukup Mudah } \\
\text { Digunakan }\end{array}$ & 2 & $10,00 \%$ \\
\hline Biasa-biasa saja & 1 & $5,00 \%$ \\
\hline
\end{tabular}

\begin{tabular}{|l|c|c|}
\hline \multicolumn{1}{|c|}{ Jawaban } & $\begin{array}{c}\text { Jumlah } \\
\text { Responden }\end{array}$ & $\begin{array}{c}\text { Prosentase } \\
(\mathbf{\%})\end{array}$ \\
\hline $\begin{array}{l}\text { Sangat mudah } \\
\text { dipelajari }\end{array}$ & 5 & $25,00 \%$ \\
\hline Mudah Dipelajari & 12 & $60,00 \%$ \\
\hline $\begin{array}{l}\text { Cukup Mudah } \\
\text { Dipelajari }\end{array}$ & 3 & $15,00 \%$ \\
\hline Biasa-biasa saja & - & - \\
\hline $\begin{array}{l}\text { Cukup Sulit } \\
\text { Dipelajari }\end{array}$ & - & - \\
\hline Sulit Dipelajari & - & - \\
\hline $\begin{array}{l}\text { Sangat Sulit } \\
\text { Dipelajari }\end{array}$ & - & - \\
\hline Jumlah & $\mathbf{2 0}$ & $\mathbf{1 0 0 \%}$ \\
\hline $\begin{array}{l}\text { Cukup sulit } \\
\text { digunakan }\end{array}$ & - & - \\
\hline Sulit digunakan & - & - \\
\hline $\begin{array}{l}\text { Sangat Sulit } \\
\text { digunakan }\end{array}$ & - & $\mathbf{1 0 0 \%}$ \\
\hline Jumlah & $\mathbf{2 0}$ & $\mathbf{~}$ \\
\hline A & & \\
\hline pakah aplikasi & - & \\
\hline
\end{tabular}

2. Apakah aplikasi sistem pakar yang dibangun mudah untuk dipelajari?

Tabel 4.2 Hasil Prosentasi aplikasi mudah untuk dipelajari.
3. Apakah tampilan antarmuka dari aplikasi ystem pakar terlihat menarik?

Tabel 4.3 Hasil Prosentasi aplikasi terlihat menarik

\begin{tabular}{|l|c|c|}
\hline \multicolumn{1}{|c|}{ Jawaban } & $\begin{array}{c}\text { Jumlah } \\
\text { Responden }\end{array}$ & $\begin{array}{c}\text { Prosentase } \\
(\mathbf{\%})\end{array}$ \\
\hline Sangat Menarik & - & - \\
\hline Menarik & 2 & $10,00 \%$ \\
\hline Cukup Menarik & 15 & $75,00 \%$ \\
\hline Biasa-biasa saja & 2 & $10,00 \%$ \\
\hline Kurang Menarik & 1 & $5,00 \%$ \\
\hline Tidak Menarik & - & - \\
\hline $\begin{array}{l}\text { Sangat Tidak } \\
\text { Menarik }\end{array}$ & - & - \\
\hline Jumlah & $\mathbf{2 0}$ & $\mathbf{1 0 0 \%}$ \\
\hline
\end{tabular}

4. Apakah aplikasi sistem pakar ini dapat membantu dalam mengidentifikasi penyakit demam berdarah ? Tabel 4.4 Hasil prosentase aplikasi membantu dalam mengidentifikasi demam berdarah

\begin{tabular}{|l|c|c|}
\hline Jawaban & $\begin{array}{c}\text { Jumlah } \\
\text { Responden }\end{array}$ & $\begin{array}{c}\text { Prosentase } \\
\text { (\%) }\end{array}$ \\
\hline $\begin{array}{l}\text { Sangat } \\
\text { Membantu }\end{array}$ & 2 & $10,00 \%$ \\
\hline Membantu & 5 & $25,00 \%$ \\
\hline $\begin{array}{l}\text { Cukup } \\
\text { Membantu }\end{array}$ & 13 & $65,00 \%$ \\
\hline Biasa-biasa saja & - & - \\
\hline $\begin{array}{l}\text { Kurang } \\
\text { Membantu }\end{array}$ & - & - \\
\hline $\begin{array}{l}\text { Tidak } \\
\text { Membantu }\end{array}$ & - & - \\
\hline $\begin{array}{l}\text { Sangat Tidak } \\
\text { Membantu }\end{array}$ & - & - \\
\hline Jumlah & $\mathbf{2 0}$ & $\mathbf{1 0 0 \%}$ \\
\hline
\end{tabular}

5. Apakah gejala dan penyakit pada aplikasi ini sesuai dengan kenyataan?

Tabel 4.5 Hasil prosentase aplikasi sesuai dengan kenyataan.

\begin{tabular}{|l|c|c|}
\hline Jawaban & $\begin{array}{c}\text { Jumlah } \\
\text { Responden }\end{array}$ & $\begin{array}{c}\text { Prosentase } \\
(\mathbf{\% )}\end{array}$ \\
\hline Sangat Sesuai & 2 & $10,00 \%$ \\
\hline Sesuai & 3 & $15,00 \%$ \\
\hline Cukup Sesuai & 13 & $65,00 \%$ \\
\hline Biasa-biasa saja & 2 & $10,00 \%$ \\
\hline Kurang Sesuai & - & - \\
\hline Tidak Sesuai & - & - \\
\hline $\begin{array}{l}\text { Sangat Tidak } \\
\text { Sesuai }\end{array}$ & - & - \\
\hline Jumlah & $\mathbf{2 0}$ & $\mathbf{1 0 0 \%}$ \\
\hline
\end{tabular}


6. Apakah hasil kesimpulan dan informasi aplikasi sistem pakar ini akurat?

Tabel 4.6 Hasil prosentase keakuratan aplikasi.

\begin{tabular}{|l|c|c|}
\hline Jawaban & $\begin{array}{c}\text { Jumlah } \\
\text { Responden }\end{array}$ & $\begin{array}{c}\text { Prosentase } \\
(\mathbf{\%})\end{array}$ \\
\hline Sangat Akurat & - & - \\
\hline Akurat & 4 & $25,00 \%$ \\
\hline Cukup Akurat & 14 & $65,00 \%$ \\
\hline Biasa-biasa saja & 2 & $10,00 \%$ \\
\hline Kurang Akurat & & \\
\hline Tidak Akurat & & \\
\hline $\begin{array}{l}\text { Sangat Tidak } \\
\text { Akurat }\end{array}$ & & $\mathbf{1 0 0 \%}$ \\
\hline Jumlah & $\mathbf{2 0}$ & \\
\hline
\end{tabular}

\subsection{Kesimpulan Hasil Pengujian Betha}

Berdasarkan hasil prosentase diatas didapatkan dari pengujian betha, yang dibagikan kepada 20 orang yang mengatakan bahwa perangkat lunak yang dibangun sudah mudah digunakan, mudah untuk dipelajari, tampilan antarmuka menarik, cukup membantu dalam mengidentifikasi penyakit dan gejala pada aplikasi ini sesuai dengan kenyataan, dan menghasilkan kesimpulan yang cukup akurat.

Tabel 4.7 Hasil prosentase betha

\begin{tabular}{|l|c|c|}
\hline \multicolumn{1}{|c|}{ Jawaban } & $\begin{array}{c}\text { Jumlah } \\
\text { Responden }\end{array}$ & Prosentase \\
\hline $\begin{array}{l}\text { Mudah } \\
\text { digunakan }\end{array}$ & 20 & $100 \%$ \\
\hline $\begin{array}{l}\text { Mudah } \\
\text { dipelajari }\end{array}$ & 20 & $100 \%$ \\
\hline $\begin{array}{l}\text { Tampilan } \\
\text { menarik }\end{array}$ & 20 & $100 \%$ \\
\hline $\begin{array}{l}\text { Cukup } \\
\text { membantu }\end{array}$ & 20 & $100 \%$ \\
\hline Jumlah & $\mathbf{2 0}$ & $\mathbf{1 0 0 \%}$ \\
\hline
\end{tabular}

\section{PENUTUP}

\subsection{Kesimpulan}

Dari hasil pengujian dan analasis sistem pakar diagnosa penyakit didaerah tropis pada anak berbasis web, maka dapat disimpulkan hal-hal sebagai berikut.

1. Aplikasi dibangun berbasis dengan bahasa pemrograman PHP dan basis data MySQL.

2. Basis pengetahuan sistem pakar berdasarkan penyakit dan gejala yang sering ditangani oleh pakar.

3. Berdasarkan hasil prosentase dari pengujian betha, perangkat lunak yang dibangun sudah mudah digunakan, mudah untuk dipelajari, tampilan antarmuka menarik, cukup membantu dalam mengidentifikasi penyakit dan gejala pada aplikasi ini sesuai dengan kenyataan, dan menghasilkan kesimpulan yang cukup akurat, dan aplikasi dapat berjalan dengan baik.

4. Berdasarkan hasil pengujian alpha, perangkat lunak yang dibangun sudah berjalan cukup maksimal, tetapi tidak menutup kemungkinan dapat terjadi kesalahan pada suatu saat aplikasi digunakan. Sehingga membutuhkan proses maintenance untuk lebih mengetahui kekurangan dari aplikasi.

5. Aplikasi sistem pakar diagnosa penyakit didaerah tropis pada anak berbasis web ini merupakan pengaplikasian kemampuan dan pengalaman seorang pakar dalam mendiagnosis penyakit dalam bentuk suatu aplikasi yang dapat digunakan oleh pelanggan untuk mendiagnosis penyakit yang mempunyai batasan masalah adalah demam berdarah.

6. Aplikasi sistem pakar ini tetap harus memeriksa darah ke laboratorium agar penyakit yang diderita pasien lebih akurat 


\subsection{Saran}

Berdasarkan pengujian terhadap aplikasi sistem pakar diagnosa penyakit di daerah tropis pada anak berbasis web yang telah dibuat, dapat diberikan beberapa saran sebagai berikut.

1. Aplikasi sistem pakar diagnosa penyakit di daerah tropis pada anak berbasis web ini dapat dikembangkan lebih lanjut dengan menambahkan beberapa fitur yang belum dimasukkan ke dalam aplikasi.

2. Aplikasi sistem pakar diagnosa penyakit didaerah trpis pada anak berbasis web ini dapat di buat versi mobile nya, sehingga lebih mempermudah pemakai.

3. Memperbaiki dan memperindah tampilan antarmuka untuk menyajikan kenyamanan penggunaan oleh pengguna.

4. Menyajikan solusi penyakit yang lebih detil dengan langkah-langkah penanganan yang rinci dan disertai dengan gambar.

\section{DAFTAR PUSTAKA}

Arhami, Muhammad. Konsep Dasar Sistem Pakar. Andi. 2005. Yogyakarta.

Kristanto, Andri. Kecerdasan Buatan Cetakan Pertama. Graha Ilmu. 2004. Yogyakarta.

Kusumadewi, Sri. Artificial Intelegence (Teknik dan Aplikasinya) Cetakan Kedua. Graha Ilmu. 2003. Yogyakarta.

Peranginangin, Kasiman. Aplikasi Web dengan PHP dan MySQL. Andi. 2007. Yogyakarta.

Bahtiar, Agus. PHP/SCRIPT/MOST WANTED Cetakan Kedua . Kriya Pustaka. 2009. Depok.

Kusrini. Sistem Pakar Teori dan Aplikasi. Andi. 2006. Yogyakarta.

Hirin A.M dan Virgi. Cepat Mahir Pemrograman Web dengan PHP dan MySQL. Prestasi Pustakaraya.2011. Jakarta.

Nugroho, Bunafit. Latihan Membuat Aplikasi Web PHP dan MySQL dengan Dreamweaver, Gaya Media. 2008. Yogyakarta, 